\title{
Durability of resistance to stripe rust in the wheat cultivar 'Claire' in New Zealand
}

\author{
S.F. Chng, M.G. Cromey and S.C. Shorter \\ The New Zealand Institute for Plant E Food Research Limited, Private Bag 4704, \\ Christchurch 8140, New Zealand \\ Corresponding author: soonie.chng@plantandfood.co.nz
}

\begin{abstract}
Host resistance is the most economical way to manage wheat stripe rust caused by Puccinia striiformis f. sp. tritici. The cultivar 'Claire' was released in 1999, and until recently, remained highly resistant to the disease in the United Kingdom. While 'Claire' was considered durably resistant to stripe rust in New Zealand, it is now categorised as moderately susceptible. The present study investigated whether race-specific resistance was responsible for this 'break-down' in resistance, and whether cv. 'Claire' retains useful durable resistance. A rust culture from cv. 'Claire' was compared with a pre-2005 culture on a set of differential cultivars. The seedling resistance in cv. 'Claire' was race-specific. Greenhouse and field experiments suggest that the adult plant resistance in cv. 'Claire' has been reduced in the presence of a more virulent stripe rust population. Remaining adult plant resistance is insufficient to provide adequate control of stripe rust in New Zealand wheat crops.
\end{abstract}

Keywords Puccinia striiformis f. sp. tritici, differentials, race-specific resistance, adult plant resistance.

\section{INTRODUCTION}

Stripe rust, caused by Puccinia striiformis Westend. f. sp. tritici Eriksson, is one of the most important diseases of wheat (Triticum aestivum L.) in New Zealand and throughout the world. The disease was first detected in Australia in 1979 (O'Brien et al. 1980) and in New Zealand in 1980 (Beresford 1982). Yield losses of between 20 and $84 \%$ have been reported in susceptible wheat cultivars (Doling \& Doodson 1968; Beresford 1982; Murray et al. 1995).

The use of wheat cultivars resistant to stripe rust is the most effective and economical approach to control the disease. Approximately 40 racespecific stripe rust resistance genes have been identified in wheat and deployed in breeding programmes (McIntosh et al. 1995; Powell et al.
2008). However, P. striiformis f.sp. tritici is highly adaptable and resistance in many wheat cultivars has been lost as a result of changes in virulence of the pathogen, which have overcome the racespecific resistance genes (Viljanen-Rollinson et al. 2006; Powell et al. 2008). The changes in virulence of the pathogen or emergence of new pathotypes of $P$. striiformis f.sp. tritici occur probably by mutation and somatic recombination (Stubbs 1985). More than 30 pathotypes of P. striiformis f.sp. tritici have been recorded in New Zealand (Viljanen-Rollinson et al. 2006). Consequently, the breeding strategy for wheat with resistance to stripe rust has focussed on developing cultivars with 'durable' resistance controlled by many loci (Powell et al. 2008). Durable resistance remains 
effective over wide areas, over long periods of time, in environmental conditions favourable to disease (Johnson 1992). One example is the New Zealand wheat cultivar 'Otane', which carries the adult plant resistance (APR) gene $\mathrm{Yr} 18$, and which has remained durably resistant to stripe rust since its release in 1984 (Ma et al. 1997). At least three resistance loci have been found to control APR to stripe rust in this population (Imtiaz et al. 2004).

The wheat cultivar 'Claire' was commercially released by Nickerson Seeds UK Ltd in the United Kingdom in 1999, where it had complete resistance to stripe rust (Powell et al. 2008). Two cultivars, 'Carstens V' and 'Cappelle Desprez', both of which are within the pedigree of $\mathrm{cv}$. 'Claire', are believed to have contributed to its APR to stripe rust. 'Cartens V' has race-specific resistance genes [Yr32 and Yr25 (Hovmoller 2007)] to many European and North American stripe rust races, and is believed to also contain partial, durable APR to stripe rust (Powell et al. 2008). 'Cappelle Desprez' carries Yr3a, Yr4a (Chen \& Line 1993) and Yr16 (Powell et al. 2008) resistance genes to stripe rust. Some race-specific seedling resistance genes postulated to be carried by cv. 'Claire' are Yr2, Yr3, Yr4, Yr25 and an unknown gene (Lewis 2006).

'Claire' was considered to be durably resistant to the prevalent stripe rust population when it was released in New Zealand. The disease was first observed on it in the field in 2005
(M.G. Cromey, unpublished data) and the cultivar is now categorised as moderately susceptible to susceptible at all growth stages (Table 1).

The present study aimed to identify the cause of the 'breakdown' of resistance in cv. 'Claire' to stripe rust, to clarify the seedling (race-specific) resistance genes present, and to identify any remaining 'background' resistance that may be durable.

\section{MATERIALS AND METHODS \\ Collection and bulking of rust cultures}

Leaves naturally infected with stripe rust were collected from field crops of cv. 'Claire' in November 2009 from Lincoln, New Zealand. Infected leaves were then placed on moistened filter papers in Petri dishes and kept at $4^{\circ} \mathrm{C}$ to encourage sporulation. After several days, susceptible wheat seedlings (cv. 'Morocco') were inoculated at the two leaf stage to increase the available inoculum. Inoculations were made by either a moistened cotton bud or by suspending the urediniospores in 2-3 $\mathrm{ml}$ of light mineral oil (Pegasol, Mobil) and atomising onto susceptible seedlings (Imtiaz et al. 2003). Inoculated seedlings were kept at $10 \pm 2^{\circ} \mathrm{C}$ at $100 \%$ relative humidity in a humidity chamber in the dark for $24 \mathrm{~h}$ and then transferred to glasshouse benches $\left(18 \pm 2^{\circ} \mathrm{C}\right)$ for 14 days. Urediniospores were then collected from pustules on leaves, using standard techniques (Imtiaz et al. 2003).

Table 1 Stripe rust observations of cv. 'Claire' in on-farm cultivar trials in New Zealand (M.G. Cromey, unpublished data).

\begin{tabular}{lcl}
\hline Year & Field resistance $^{1}$ & Comments $^{2}$ \\
\hline $2001 / 02$ & $\mathrm{R}$ & No stripe rust detected in any trials \\
$2002 / 03$ & $\mathrm{R}$ & No stripe rust detected in any trials \\
$2003 / 04$ & $\mathrm{R}$ & No stripe rust detected in any trials \\
$2004 / 05$ & $\mathrm{R}(?)$ & Trace of stripe rust detected in one trial \\
$2005 / 06$ & $\mathrm{R} / \mathrm{MR}$ & Stripe rust present in some trials \\
$2006 / 07$ & $\mathrm{R} / \mathrm{MS}$ & Stripe rust present in many trials \\
$2007 / 08$ & MSS/R & Stripe rust present in most trials \\
$2008 / 09$ & MSS/R & Stripe rust present in most trials \\
$2009 / 10$ & MSS/R & Stripe rust present in most trials \\
$2010 / 11$ & MSS & Stripe rust widespread \\
\hline
\end{tabular}

${ }^{1} \mathrm{R}=$ resistant $\mathrm{MR}=$ moderately resistant; $\mathrm{MS}=$ moderately susceptible; $\mathrm{MSS}=$ Moderately susceptible to susceptible.

${ }^{2}$ On average nine sites were monitored for stripe rust in the field each year. 


\section{Differential studies}

\section{Seedling test}

The stripe rust culture collected from cv. 'Claire' (WYR09/1) was characterised in a seedling resistance test, using a differential series of wheat cultivars comprising International and European sets based on the system established by Johnson et al. (1972), and an additional Australian series recommended by Wellings et al. (1988). An uncharacterised culture (WYR93/1; Plant \& Food Research culture collection) that was obtained from wheat cultivar 'Delphier' in 1993 (predating the occurrence of virulence to cv. 'Claire'), was included for comparison. The complete set of differential hosts (22 cultivars), including the assigned decanary values (used for designating numbers to the rust pathotypes; Johnson 1972) for the International and European sets, and three susceptible control cultivars ('Claire', 'Morocco' and 'Tiritea') are listed in Table 2.

Four seeds of a cultivar were sown in each corner of a square pot $(9 \mathrm{~cm} \times 9 \mathrm{~cm} \times 7.5 \mathrm{~cm})$ containing potting mix, giving four cultivars in each pot. The potting mix consisted of three parts shredded bark (Pinus radiata D. Don.): two parts washed crusher sand, supplemented with $6.4 \mathrm{~kg} / \mathrm{m}^{3}$ dolomite lime, $3.32 \mathrm{~kg} / \mathrm{m}^{3}$ "Osmocote 14-16.1-11.6", $104 \mathrm{~kg} / \mathrm{m}^{3}$ superphospate, $120 \mathrm{~g} / \mathrm{m}^{3}$ calcium nitrate, $56 \mathrm{~g} / \mathrm{m}^{3}$ "FetrilonCombil" (BASF) and $1 \mathrm{~kg} / \mathrm{m}^{3}$ "Micromax". There were three replicates for each cultivar. The pots were laid out in a randomised complete block design and maintained at $18 \pm 2^{\circ} \mathrm{C}$ on greenhouse benches. Seedlings were inoculated with the two rust cultures separately when two leaves were expanded and incubated using the methods described above, before returning to the greenhouse. After 14 days, the symptoms were assessed using The University of Sydney Plant Breeding Institute (PBI) 0-4 infection types (IT) scoring system outlined by McIntosh et al. (1995). Using the susceptible cultivar 'Morocco' as a standard, ITs of ' 3 ' or above in at least two replicates were considered a 'susceptible' (S) reaction and ITs below 3 were considered a 'resistant' (R) reaction.
Adult plant test in the field

A field study was conducted in Lincoln ( $S 43^{\circ} 39^{\prime}$, E172 $29^{\prime}$ ), New Zealand, in 2007/08 using similar differential series to that used in the seedling test. An additional Australian differential set, which comprised cultivars 'Avocet R' and 'Avocet S' (as a susceptible control), was also included in the study. Inoculum of $P$. striiformis f.sp. tritici was abundant at the trial location and the trial relied on natural inoculum to create an epidemic.

Test plots comprised two $1 \mathrm{~m}$ rows with each plot representing one test cultivar. The plots were adjacent to a rust spreader row, consisting of a mixture of 'Tiritea' (susceptible to all stripe rust pathotypes) and 'Claire' (to select any pathotypes virulent on cv. 'Claire').

Stripe rust was assessed on fully expanded flag leaves of the adult plants between growth stages 61 to 69 (Tottman \& Makepeace 1979) using a modified Cobb scale that included both the mean percentage of leaf area infected across each plot and host response, as outlined by McIntosh et al. (1995). Host responses were: $\mathrm{R}=$ resistant with no/few pustules present; $\mathrm{MR}=$ moderately resistant with a few pustules in necrotic tissue; MS = moderately susceptible with pustules and some necrosis/chlorosis; $\mathrm{S}$ = susceptible with many pustules and little chlorosis. An additional response, MSS, which is 'Moderately susceptible' to 'susceptible', was sometimes used when the host showed symptoms of both MS and S responses.

\section{Adult plant resistance in 'Claire' and its relatives \\ 'Claire' and 17 of its relatives were assessed for their APR to stripe rust at two field sites, Lincoln $\left(\mathrm{S} 43^{\circ} 39^{\prime}, \mathrm{E} 172^{\circ} 29^{\prime}\right)$ and Wakanui (S43 $58^{\prime}$, E171 ${ }^{\circ} 49^{\prime}$ ) in 2007/08. These trials relied on natural inoculum, which was more abundant at Lincoln than at Wakanui. The plot layout for the trials and APR disease assessments were as described above.}

\section{RESULTS}

\section{Differential studies}

The stripe rust culture, WYR93/1 (ex-'Delphier'), was characterised as pathotype $104 \mathrm{E} 137 \mathrm{~A}+$ in 
the seedling differential test. This pathotype is virulent to resistance genes $Y r 2, Y r 3, Y r 4, Y r S D$, YrSO and YrA (Table 2). Both 'Morocco' and 'Tiritea' were susceptible, while cv. 'Claire' was resistant. Culture WYR09/1 was characterised as pathotype 106E139A+YrSK+, which contains virulence to the stripe rust resistance genes $Y r 7$ and $Y r S K$, in addition to those present in pathotype 104E137A+ (culture WYR93/1).

Results from the adult plant differential test in the field revealed the presence of a wider range of virulence than in either cultures WYR93/1 or WRY09/1 (Table 3). Most notably, the differential cultivars 'Chinese 166' and 'Clement' were susceptible, indicating virulence to $\mathrm{Yr} 1$ and Yr9. Virulence to these two genes is common in the New Zealand stripe rust population. The differential cultivars 'Compair' (Yr8) and 'Spaldings Prolific' (YrSP and Yr25) were also susceptible. Virulence to these genes has also been recorded in New Zealand. Two differentials, Triticum spelta (Yr5) and 'Carstens V' (Yr32 and Yr25), were highly resistant in the trial.

Table 2 Greenhouse seedling responses of the host differential series to two P. striiformis f. sp. tritici pathotypes.

\begin{tabular}{|c|c|c|c|c|}
\hline \multirow[b]{2}{*}{ Differential cultivars } & \multirow[b]{2}{*}{ Resistance gene $^{1}$} & \multirow[b]{2}{*}{$\begin{array}{c}\text { Decanary } \\
\text { value }\end{array}$} & \multicolumn{2}{|c|}{ Host response $^{2}$ to rust culture } \\
\hline & & & $\begin{array}{c}\text { WYR93/1 } \\
\text { (ex-Delphier) }\end{array}$ & $\begin{array}{c}\text { WYR09/1 } \\
\text { (ex-Claire) }\end{array}$ \\
\hline \multicolumn{5}{|l|}{ International series } \\
\hline Chinese 166 & Yr1 & 1 & $\mathrm{R}$ & $\mathrm{R}$ \\
\hline Lee & $Y r 7$ & 2 & $\mathrm{R}$ & S \\
\hline Heines Kolben & Yr2, Yr6 & 4 & $\mathrm{R}$ & $\mathrm{R}$ \\
\hline Vilmorin-23 & $\operatorname{Yr} 3,+$ & 8 & $S$ & $S$ \\
\hline Moro & $\operatorname{Yr} 10$ & 16 & $\mathrm{R}$ & $\mathrm{R}$ \\
\hline Strubes Dickkopf & YrSD, Yr25 & 32 & $S$ & $S$ \\
\hline Suwan 92/Omar & $\mathrm{YrSO}$ & 64 & $\mathrm{~S}$ & $S$ \\
\hline Clement & $\operatorname{Yr} 2, \operatorname{Yr} 9$ & 128 & $\mathrm{R}$ & $\mathrm{R}$ \\
\hline Triticum spelta & Yr5 & 256 & $\mathrm{R}$ & $\mathrm{R}$ \\
\hline \multicolumn{5}{|l|}{ European series } \\
\hline Hybrid-46 & Yr4, + & 1 & S & S \\
\hline Reichersberg-42 & $\operatorname{Yr} 7,+$ & 2 & $\mathrm{R}$ & S \\
\hline Heines Peko & Yr2, Yr6, Yr25 & 4 & $\mathrm{R}$ & $\mathrm{R}$ \\
\hline Nord Desprez & Yr3 & 8 & $\mathrm{~S}$ & S \\
\hline Compair & $\operatorname{Yr} 8$ & 16 & $\mathrm{R}$ & $\mathrm{R}$ \\
\hline Carstens V & Yr32, Yr25, + & 32 & $\mathrm{R}$ & $\mathrm{R}$ \\
\hline Spaldings Prolific & YrSP, Yr25 & 64 & $\mathrm{R}$ & $\mathrm{R}$ \\
\hline Heines VII & Yr2, Yr25 & 128 & $\mathrm{~S}$ & $\mathrm{~S}$ \\
\hline \multicolumn{5}{|l|}{ India } \\
\hline Riebasel-47.5.1 & $\operatorname{Yr} 9$ & & $\mathrm{R}$ & $\mathrm{R}$ \\
\hline \multicolumn{5}{|l|}{ Australasian series } \\
\hline Avocet R & $Y r A$ & & $S$ & S \\
\hline Kalyansona & $Y r 2$ & & S & S \\
\hline Rendezvous & $\operatorname{Yr} 17$ & & $\mathrm{R}$ & $\mathrm{R}$ \\
\hline Selkirk & Yr27 (YrSk) & & $\mathrm{R}$ & $\mathrm{S}$ \\
\hline \multicolumn{5}{|l|}{ Susceptible control } \\
\hline Morocco & & & S & S \\
\hline Tiritea & & & $\mathrm{S}$ & S \\
\hline Claire & & & $\mathrm{R}$ & $\mathrm{S}$ \\
\hline Pathotype designation & & & 104E137A+ & 106E139A+, Yr27+ \\
\hline
\end{tabular}


Table 3 Adult plant disease scores in the field to the differential series on P. striiformis $\mathrm{f}$. sp. tritici.

\begin{tabular}{|c|c|c|c|}
\hline Differential cultivars & Resistance gene $^{1}$ & Decanary value & Disease score $^{2}$ \\
\hline \multicolumn{4}{|l|}{ International series } \\
\hline Chinese 166 & Yr1 & 1 & $75 \mathrm{MS}$ \\
\hline Lee & $Y r 7$ & 2 & $95 \mathrm{MS}$ \\
\hline Heines Kolben & $\operatorname{Yr} 2, \operatorname{Yr} 6$ & 4 & $20 \mathrm{MS}$ \\
\hline Vilmorin 23 & $Y r 3,+$ & 8 & $30 \mathrm{MS}$ \\
\hline Moro & $\operatorname{Yr} 10$ & 16 & $30 \mathrm{MR}$ \\
\hline Strubbes Dickoph & YrSD, Yr25 & 32 & $45 \mathrm{MR}$ \\
\hline Suwon 92/Omar & YrSO & 64 & $100 \mathrm{~S}$ \\
\hline Clement & $\operatorname{Yr} 2, \operatorname{Yr} 9$ & 128 & 65 MSS \\
\hline Triticum spelta & Yr5 & 256 & $10 \mathrm{R}$ \\
\hline \multicolumn{4}{|l|}{ European series } \\
\hline Hybrid 46 & $Y r 4,+$ & 1 & $10 \mathrm{MR}$ \\
\hline Reichersberg 42 & $\operatorname{Yr} 7,+$ & 2 & $30 \mathrm{MS}$ \\
\hline Heines Peko & Yr2, Yr6, Yr25 & 4 & $20 \mathrm{MS}$ \\
\hline Nord Desprez & $Y r 3$ & 8 & $70 \mathrm{~S}$ \\
\hline Compair & $\operatorname{Yr} 8$ & 16 & $80 \mathrm{MS}$ \\
\hline Carstens V & $\operatorname{Yr} 32, \operatorname{Yr} 25,+$ & 32 & $5 \mathrm{R}$ \\
\hline Spaldings Prolific & YrSP, Yr25 & 64 & $70 \mathrm{MS}$ \\
\hline Heines VII & Yr2,Yr25 & 128 & $100 \mathrm{MS}$ \\
\hline \multicolumn{4}{|l|}{ India } \\
\hline Riebesel 47 & $\operatorname{Yr} 9$ & & $40 \mathrm{MS}$ \\
\hline \multicolumn{4}{|l|}{ Australian series } \\
\hline Avocet R & $\operatorname{YrA}$ & & $80 \mathrm{MS}$ \\
\hline Avocet S & - & & $100 \mathrm{~S}$ \\
\hline
\end{tabular}

${ }^{1}$ References for Yr genes in Hovmoller (2007) and McIntosh et al. (1995).

${ }^{2} \mathrm{R}=$ resistant with no/few pustules present; $\mathrm{MR}=$ moderately resistant with a few pustules in necrotic tissue; $\mathrm{MS}=$ moderately susceptible with pustules and some necrosis/chlorosis; $\mathrm{S}=$ susceptible with many pustules and little chlorosis; MSS = moderately susceptible to susceptible. The number refers to the percent leaf area infected.

\section{Adult plant resistance stripe rust}

Stripe rust was more severe at the Lincoln trial than at Wakanui (Table 4). The cultivar 'Claire' was the most heavily infected in the Lincoln trial and one of the most infected at Wakanui. Several of the ancestors or relatives of cv. 'Claire' had low disease severity at both trials, while some had almost as much disease as cv. 'Claire' at Lincoln, but little or no disease at Wakanui. For instance, both parents ('Flame' and 'Wasp') were heavily infected at Lincoln, while only cv. 'Wasp' had more than a trace of stripe rust at Wakanui. 'Capelle Desprez' was one of the more severely infected cultivars at both trials.

\section{DISCUSSION}

The wheat cultivar, 'Claire', was highly resistant to stripe rust in New Zealand from the time of its release in 2001 until at least 2005, when traces of rust were detected in one cultivar evaluation field trial. Since then, stripe rust has become widespread on cv. 'Claire' in New Zealand, and the cultivar is now regarded as moderately susceptible to susceptible to the disease.

The stripe rust pathotype virulent on cv. 'Claire' was characterised as 106E139A+Yr27+, which has been common in New Zealand since the 1990s (M.G. Cromey, unpublished data), prior to cv. 'Claire' being released in this country. Given 
Table 4 Adult plant disease scores of cultivar 'Claire' and relatives in the field to P. striiformis f.sp. tritici.

\begin{tabular}{llll}
\hline Cultivars & & \multicolumn{2}{l}{ Disease score } \\
\cline { 2 - 3 } ('Claire' and relatives) & Relationship to 'Claire' & Lincoln & Wakanui \\
\hline Claire & - & $40 \mathrm{MSS}$ & $25 \mathrm{~S}$ \\
Flame & Parent of 'Claire' & $30 \mathrm{MS}$ & $2 \mathrm{MR}$ \\
Wasp & Parent of 'Claire' & $30 \mathrm{MS}$ & $30 \mathrm{~S}$ \\
Boxer & Grandparent of 'Claire' & $10 \mathrm{MS}$ & $0 \mathrm{R}$ \\
Taurus & Grandparent of 'Claire' & $10 \mathrm{MR}$ & $0 \mathrm{R}$ \\
Armada & Great grandparent of 'Claire' & $15 \mathrm{MR}$ & $0 \mathrm{R}$ \\
Buster & Related to 'Claire' & $40 \mathrm{MR}$ & $0 \mathrm{R}$ \\
Zodiac & Related to 'Claire' & $10 \mathrm{MSS}$ & $0 \mathrm{R}$ \\
Dynamo & Related to 'Claire' & $20 \mathrm{MS}$ & $5 \mathrm{MS}$ \\
Parade & Related to 'Claire' & $25 \mathrm{MR}$ & $0 \mathrm{R}$ \\
Aquila & Related to 'Claire' & $10 \mathrm{MR}$ & $0 \mathrm{R}$ \\
Deben & Related to 'Claire' & $15 \mathrm{MS}$ & $0 \mathrm{R}$ \\
Alcedo & (Rekord x Poros) $\times$ 'Carsten III' & $10 \mathrm{MR}$ & $0 \mathrm{R}$ \\
Estica & 'Carstens VII' derivative & $20 \mathrm{MR}$ & $0 \mathrm{R}$ \\
Caribo & Ancestor of 'Claire' & $30 \mathrm{MSS}$ & $0 \mathrm{R}$ \\
Cappelle Desprez & Ancestor of 'Claire' & $35 \mathrm{MSS}$ & $10 \mathrm{MR}$ \\
Kranich & Ancestor of 'Parade' & $35 \mathrm{MS}$ & $70 \mathrm{~S}$ \\
Nijinsky & 'Claire' x 'Consort' & $25 \mathrm{MR}$ & $0 \mathrm{R}$ \\
\hline
\end{tabular}

${ }^{1} \mathrm{R}=$ resistant with no/few pustules present; $\mathrm{MR}=$ moderately resistant with a few pustules in necrotic tissue; MS = moderately susceptible with pustules and some necrosis/chlorosis; $\mathrm{S}=$ susceptible with many pustules and little chlorosis; MSS = moderately susceptible to susceptible. The number refers to the percent leaf area infected.

the change in disease reaction on cv. 'Claire' from a resistant infection type to a susceptible one in the seedling differential study (Table 2), it is likely that the cultivar contains a seedling resistance gene not present in the standard differential series. Furthermore, it is unlikely to carry resistance gene $\mathrm{Yr} 32$ from its ancestor cv. 'Carstens V', since the ex-'Claire' pathotype $(106 \mathrm{E} 139 \mathrm{~A}+\mathrm{Yr} 27+)$ is avirulent on cv. 'Carstens V' (Table 2), which also remains highly resistant in the field in New Zealand. Hovmoller (2007), who screened 141 European wheat cultivars against 16 varied stripe rust pathotypes, was unable to identify the seedling resistance gene(s) present in cv. 'Claire' (one of only 14 cultivars where the genes could not to be postulated).

The underlying APR of cv. 'Claire' was masked by its effective seedling resistance until the new 'Claire' pathotype emerged. Cultivar 'Claire' retains a modest degree of resistance to stripe rust in New Zealand. For instance, the highly susceptible cv. 'Avocet S' received a score of 100S (leaves fully covered with pustules with little or no chlorosis or necrosis). In spite of retaining some resistance to stripe rust, cv. 'Claire' is now one of the most susceptible cultivars grown commercially in New Zealand.

Both 'Capelle Desprez' and 'Carstens V' have been extensively used for stripe rust resistance breeding in Europe, because of their purported durable resistance (Powell et al. 2008). Virulence on cV. 'Carstens V' is common in eastern and central Europe and South America, but uncommon in southern Europe and southeast Asia and Australasia (Stubbs 1985; McIntosh et al. 1995). 'Carstens V', while known to have racespecific resistance to stripe rust, is also believed to contain partial, durable APR to stripe rust (Powell et al. 2008). Preliminary analysis shows that the stripe rust resistance in cv. 'Claire' (which includes both 'Capelle Desprez' and 'Carstens V' in its pedigree) is polygenic, possibly including 
the durable stripe rust APR gene Yr16, derived from cv. 'Capelle Desprez' (Powell et al. 2008). 'Capelle Desprez' had only marginally more APR in the present field trial than cv. 'Claire', which suggests that either Yr16 has become less effective in New Zealand or it confers only a modest degree of resistance.

The more severe infection at the Lincoln trial than at Wakanui (Table 4) could be due to more stripe rust inoculum present or to pathotype differences between the two sites. In addition, APR genes are often more sensitive to environmental variables (Powell 2010), and therefore may react differently to the stripe rust race in the two regions where climatic difference may have occurred.

At the time of its commercial release in the UK, cv. 'Claire' was given a rating of 9 (maximum resistance) for resistance to stripe rust, a rating it retained until as recently as 2008 . However, there is a recent (February 2011) report of increased stripe rust in cv. 'Claire' in UK breeding programmes, with the suggestion that the 'Claire' pathotype is responsible (Anon. 2011). If so, it appears likely that the current susceptibility of cv. 'Claire' to stripe rust in New Zealand is due to a breakdown both of seedling resistance gene(s) and the APR (possibly Yr16) previously believed to be durable. However, the APR resistance gene Yr16 has already been reported to be overcome by some pathotypes in France (Mallard et al. 2005), suggesting that another APR gene may be overcome by the 'Claire' pathotype in New Zealand. Investigation of APR against a range of New Zealand stripe rust cultures under controlled conditions will be required to further elucidate the durability of components of APR in cv. 'Claire'.

\section{ACKNOWLEDGEMENTS}

This project was funded by the New Zealand Foundation for Research, Science and Technology through Contract C06X0810. Catherine Munro and Ross Hanson managed the field trials.

\section{REFERENCES}

Anon. 2011. Yellow rust detected in Essex. www. farminguk.com/news/Yellow-rust-detectedin-Essex_19861.html (accessed 4 April 2011).

Beresford RM 1982. Stripe rust (Puccinia striiformis), a new disease of wheat in New Zealand. Cereal Rusts Bulletin 10: 35-41.

Chen X, Line R 1993. Inheritance of stripe rust resistance in wheat cultivars postulated to have resistance genes at Yr3 and Yr4 loci. Phytopathology 83: 382-388.

Doling DA, Doodson JK 1968. The effect of yellow rust on the yield of spring and winter wheat. Transactions of the British Mycological Society 51: 427-434.

Hovmoller MS 2007. Sources of seedling and adult plant resistance to Puccinia striiformis f.sp tritici in European wheats. Plant Breeding 126: 225-233.

Imtiaz M, Cromey MG, Hampton JG, Hill MJ 2003. Inheritance of seedling resistance to stripe rust (Puccinia striiformis $\mathrm{f}$. sp tritici) in 'Otane' and 'Tiritea' wheat (Triticum aestivum). New Zealand Journal of Crop and Horticultural Science 31: 15-22.

Imtiaz M, Ahmad M, Cromey MG, Griffin WB, Hampton JG 2004. Detection of molecular markers linked to the durable adult plant stripe rust resistance gene Yr18 in bread wheat (Triticum aestivum L.). Plant Breeding 123: 401-404.

Johnson R 1972. Nomenclature for physiologic races of Puccinia striiformis infecting wheat. Transactions of the Bristish Mycological Society 58: 475-480.

Johnson R 1992. Past, present and future opportunities in breeding for disease resistance, with examples from wheat. Euphytica 63: 3-22.

Lewis CM 2006. The genetic basis of Puccinia striiformis resistance in UK wheat germplasm. $\mathrm{PhD}$ thesis. University of East Anglia, Norwich. 
Ma H, Singh RP, Abdalla O 1997. Resistance to stripe rust in five durum wheat cultivars. Plant Disease 81: 27-30.

Mallard S, Gaudet D, Aldeia A, Abelard C, Besnard AL, Sourdille P, Dedryver F 2005. Genetic analysis of durable resistance to yellow rust in bread wheat. Theoretical and Applied Genetics 110: 1401-1409.

McIntosh RA, Wellings CR, Park RF 1995. Wheat rusts: an atlas of resistance genes. Kluwer Academic Publishers, Dordrecht, Netherlands. 200 p.

Murray GM, Ellison PJ, Watson A 1995. Effects of stripe rust on the wheat plant. Australasian Plant Pathology 24: 261-270.

O'Brien L, Brown JS, Young RM, Pascoe I 1980. Occurrence and distribution of wheat stripe rust in Victoria and susceptibility of commercial wheat cultivars. Australasian Plant Pathology 9: 14.

Powell N, Berry S, Boyd L 2008. The genetic characterisation of adult plant resistance to yellow rust in the winter wheat cultivar Claire. The 11th International Wheat Genetics Symposium Proceedings, 24-29 August 2008, Brisbane Convention Centre, Brisbane. Pp. 1-3.
Powell NM 2010. Phenotypic and genetic analysis of yellow rust resistance in the UK winter wheat cultivar Claire. $\mathrm{PhD}$ thesis. University of East Anglia, Norwich. 241 p.

Stubbs RW 1985. Stripe rust: the cereal rusts II: diseases, distribution, epidemiology, and control. Academic Press, New York.

Tottman DR, Makepeace RJ 1979. An explanation of the decimal code for the growth stages of cereals, with illustrations. Annual of Applied Biology 93: 221-234.

Viljanen-Rollinson SLH, Marroni MV, Butler RC 2006. Wheat stripe rust control using fungicides in New Zealand. New Zealand Plant Protection 59: 155-159.

Wellings CR, McIntosh RA, Hussain M 1988. A new source of resistance to Puccinia striiformis f. sp. tritici in spring wheats (Triticum aestivum). Plant Breeding 100: 88-96. 